UDC 621.391

\title{
FORMATION OF A WIRELESS COMMUNICATION SYSTEM BASED ON A SWARM OF UNMANNED AERIAL VEHICLES
}

\author{
Serhii O. Kravchuk, Liana O. Afanasieva \\ The Institute of Telecommunication Systems \\ Igor Sikorsky Kyiv Politechnic Institute, Kyiv, Ukraine
}

Background. Currently, a new direction in the technology of mobile systems is rapidly developing, associated with the use of a set / group of mobile multifunctional elements that can create different spatially-distributed structures for various applications: from entertainment shows to intelligence networks. This is a technique of small unmanned aerial vehicles (UAV), often called drones, and their use in the field of building telecommunication systems.

Objective. The aim of the work is to develop the basic principles and strategies for the formation of a heterogeneous wireless communication system based on a swarm of unmanned aerial vehicles.

Methods. We study the structural and functional methods of building a wireless network.

Results. Scenarios of centralized and distributed building of a wireless network of control of a swarm of UAVs are presented, assessment of the complexity of the functionality of swarm nodes in the case of a distributed scenario is carried out. A scheme of phased implementation of the life cycle of a UAV swarm for communication services has been developed. The "molecular" scenario of spatial self-organization of the swarm-nodes of the swarm is presented, which can be implemented using the "chain" and "flash" procedures. The proposed construction of some strategies for managing the swarm: centralized and decentralized with the Leader, collective self-management with information sharing, decentralized management with forecasting, self-organization without information sharing.

Conclusions. The basic principles and strategies for the formation of a heterogeneous wireless communication system based on a swarm of unmanned aerial vehicles have been developed. A collective management strategy for a swarm of drones was developed.

Keywords: swarm of unmanned aerial vehicles; drone swarm; communication system; life cycle; control network.

\section{INTRODUCTION}

Currently, a new direction in the technology of mobile systems is rapidly developing, associated with the use of a set / group of mobile multifunctional elements that can create different spatially-distributed structures for various applications: from entertainment shows to intelligence networks. We are talking about the technique of small unmanned aerial vehicles (UAVs), often called drones [1]-[3], and their use in the field of telecommunication systems.

The principles of self-organization and self-management of arbitrarily distributed nodes and devices for the formation of communication channels between certain points/nodes of a network have been developed for terrestrial distributed networks, mainly single-level [4]-[8]. As an example, ad hoc and mesh networks have become classical [9]. Such approaches were extended to scenarios with mobile network nodes, which led to the emergence of wireless decentralized networks MANET (Mobile Ad hoc Network) [10], data exchange systems between the car and other road infrastructure objects VANET (Vehicle Ad hoc Network) and V2X (Vehicle -to-Everything) [11].

In addition, the huge developments in the field of robotics that exist to date have allowed for the creation of a new approach to coordinating the systems of many robots - Swarm Robots, which consist of a large number of mostly simple robots [12], [13]. It is assumed that the desired collective behavior arises from the interaction of robots with each other and their interaction with the environment. This approach relates to the scientific direction of artificial swarm intelligence, which arose when conducting biological studies of insects, in particular, ants and bees, as well as in research in other areas of nature where swarm behavior is taking place. The results of studies on the management of such groups of robots moving on the surface of the Earth have shown high efficiency in using such a high-altitude aircraft as the head coordinating unit of the group [14].

Modern telecommunication networks are becoming increasingly heterogeneous in both physical and network levels, and it is desirable that they can self-organize and selfadjust, adapting to new situations in terms of traffic, services, network connection, etc. To support this, the new paradigm of the future network algorithms must be reliable, work in a distributed way, be able to observe changes in the network and adapt to them.

An example of such an algorithm is the so-called Swarm Intelligence (Swarm Intelligence), which uses mobile software agents to manage the network [15]. These agents are autonomous objects, both proactive and reactive, and are able to adapt, interact, and intelligently move from one place to another in a communication network. In particular, swarm intelligence uses stigmergy (i.e. communication through the 
environment) to interact with the agent. Swarm's intellect exhibits emergent behavior, when simple interactions of autonomous agents with simple primitives lead to complex behavior that was not explicitly defined.

Developments on the creation of complex multifunctional telecommunication stations based on HAPS (high-altitude platforms system) allowed to create a theoretical basis for the use of aerial platforms for various telecommunication applications, as well as the principles of creating a national multi-level telecommunications network [16]-[19]. In such a network, communication stations based on aero platforms are important nodes of spatial levels that allow you to interconnect ground and satellite communications, to form a threedimensional telecommunications network. However, a heavy aircraft with the ability to perform many telecommunications functions for a long time was considered as an air platform. For example, as a base station of a terrestrial wireless broadband radio access system [20].

The increasing complexity of the architecture of modern information and telecommunications networks associated with an increase in the capacity of communication channels (streaming video, transferring large amounts of data) with a sharp increase in the number of serviced user terminals (Internet things, machine-to-machine interaction) requires new flexible system solutions and technologies. In this case, intensive use of modern technologies of distributed cloud computing, self-organization, intellectualization, cooperative relaying, cognitive radio, space-time processing, adaptation, SDR (software defined radio), SoC (System-on-chip), SDN (Software-Defined Network) and others. On the basis of recent technology, as an example, as LEO satellites developed microrepeaters weighing 4 grams and measuring $3.5 \mathrm{~cm}$ (square) [21]. The development of artificial intelligence, the growth of opportunities in autonomous movement and the connection of many objects with each other are increasing interest in the use of small-sized unmanned vehicles. So, according to the program of building UAVs, the Research Laboratory of the US Navy LOCUST was created. The abbreviation in the title stands for Low-Cost Unmanned Aerial Vehicle Swarming Technology (technology "swarming" economical unmanned aerial vehicles).

Thus, to date, there has been a need to implement a multifunctional heterogeneous and distributed wireless communication system based on modern technologies, the implementation of which can be quite effective precisely through the use of a swarm of UAVs or drones. Therefore, the purpose of this work is to develop basic principles and strategies for the formation of a heterogeneous wireless communication system based on a swarm of unmanned aerial vehicles.

\section{SWARM AS A DISTRIBUTED COMMUNICATION SYSTEM STRUCTURE}

In general, a swarm of UAVs or drones can perform the same functions as a traditional multi-functional heavy UAV. The main difference in this case will be in the structure of the swarm itself - spatially distributed, and not concentrated in one construct. That is, compared with one UAV, the swarm is much more complicated both by the constructive of its nodes and by the methods of controlling the nodes in the swarm. However, precisely because of its distributed nature, the swarm has a higher survivability and flexibility in the provision of communication services.

The block diagram of the main units of the traditional UAV is shown in Fig. 1. The on-board computer is the central system responsible for the digital processing of all incoming on-board and retrieved from on-board equipment (that relates to the payload) information. A communication system on board is determined by transceiver blocks via radio data transmission, control and telemetry channels, as well as an antenna system that contains an antenna or antenna array with a guidance or tracking mechanism. And, as a rule, antennas for the control channel and data transmission can be different, since the bandwidth requirements for them are very different.

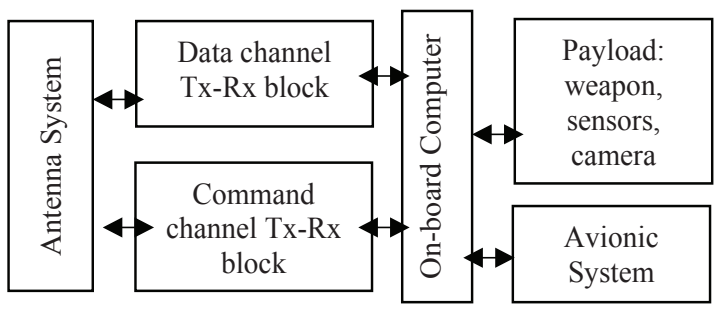

Fig. 1. The block diagram of the onboard equipment UAV

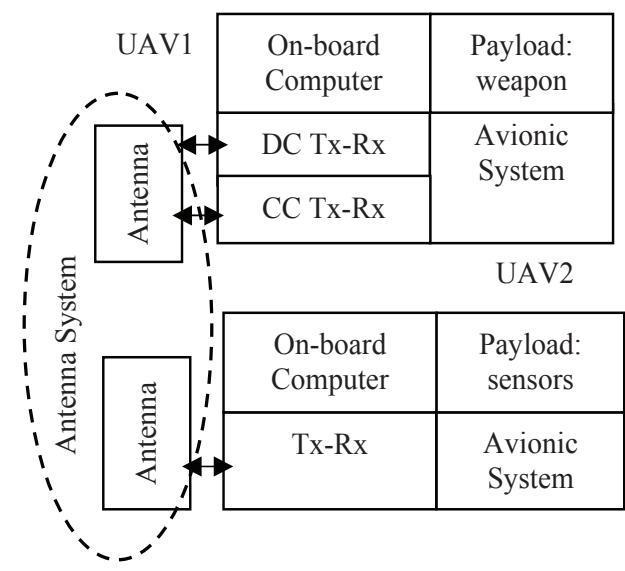

Fig. 2. Block diagram of the equipment of the UAV in a swarm: DC Tx$\mathrm{Rx}$ - Data channel Tx-Rx block; CC Tx-Rx - Command channel Tx-Rx block; Tx-Rx - generalized Tx-Rx block

In the case of a swarm of drones (two or more UAVs), the concentrated unit of on-board equipment, shown in Fig. 1, is transformed into a complex distributed structure of small nodes, as shown in Fig. 2. All the major nodes of the traditional communication UAV undergo changes. The swarm antenna system is a distributed antenna system of individual elements mounted on the swarm drones, capable of managing their own radiation pattern using spatial changes in the position of the drones [22, 23]. If necessary, each drone antenna is able to serve the needs of the onboard equipment of its drone. The rationality of the use of individual or single antennas for the operation of data and control radio channels 
on a drone depends on the purpose for which this swarm will be used, mainly for the necessary degree of security of radio channels. The same applies to installing separate or single transceivers on board swarm drones. In contrast to a heavy $\mathrm{UAV}$, in a small drone, the payload can be significantly limited. Therefore, each of the swarm drones carries a different payload, and so that, in total, the swarm carries all the distributed payload of the swarm necessary for its actions.

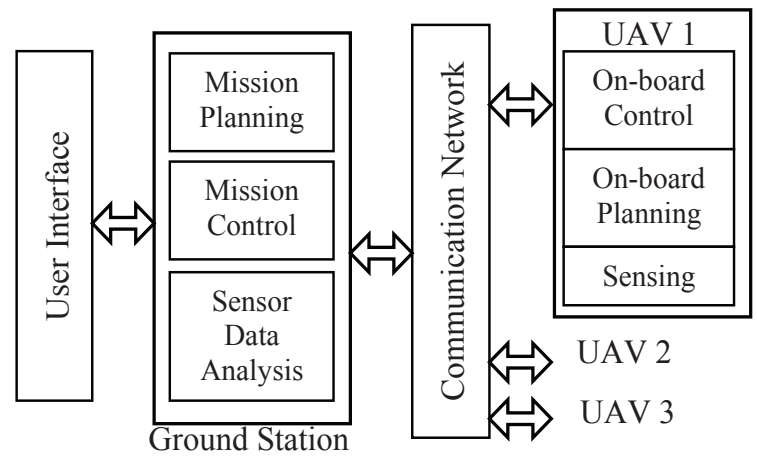

Fig. 3. Centralized swarm control network

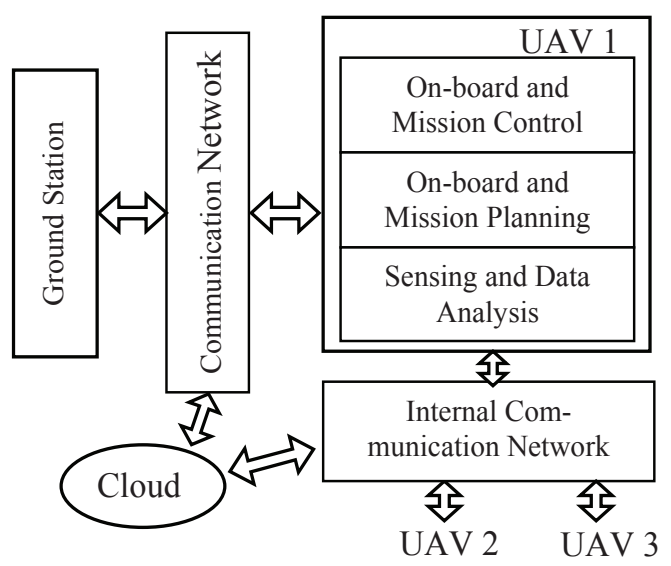

Fig. 4. Distributed swarm control network

Scenarios for constructing a control communication network in the form of functional diagrams are presented in Fig. 3 and 4. Traditionally, such a network has a user interface through which the UAV is controlled by a human; ground control station, which monitors the passage of the mission, its planning, as well as the processing (analysis) of the received data from the UAV; wireless communication network formed between the antenna elements of the ground station and the $\mathrm{UAV}$; the UAV itself, which carry out onboard control and planning, relating only to the UAV itself. Fig. 3 presents the scenario of building a control network of a UAV group, that is, a swarm of drones, according to the traditional centralized control scheme. Such a scenario is quite applicable for a small swarm consisting of a small number of UAVs. More promising for a large number of small UAVs compared with the traditional scheme is a distributed control scheme (Fig. 4). Here, the participation of a person is limited to the maximum, as is the impact of the ground station in controlling the functioning of the swarm. At the same time, the functionality of swarm nodes is complicated, and an isolated wireless swarm control network is formed between the swarm nodes. The complication of the swan node's functionality is due to the fact that the node should now participate in joint storage and analysis of what the ground station performed in the centralized control scheme: monitoring the fulfillment of the swarm mission, planning it, and analyzing the data received from the sensors and navigation system. For its work, the swarm can connect not only to the command ground station, but also to any cloud resource, while working with wireless devices such as Internet things. Thus, the swarm can become part of a large network of M2M machine-to-machine interaction technology (Machine-to-Machine) [24]. In this case, the main functions are ensuring self-organization and self-government.

Swarm can be disposable and reusable. At the same time, swarm nodes can be structured in two ways: all small-sized and equal nodes (as with ad hoc) [25] or with one or more head (lead) nodes based on "heavy" multifunctional dronesnodes (as with mesh) [26, 27].

The flexible distributed system of a swarm of drones can be part of a traditional communication system, for example, perform the role of a base station node (in the relay mode) in a mobile cellular communication network, a broadband radio access system [28-31]. Also, on the basis of the swarm can be formed separate relay channels [32] and unique in its purpose combined relay communication systems $[33,34]$.

\section{SWARM WORK LIFE CYCLE}

The life cycle of the work of the swarm, or rather the work of the drone-nodes, which form the swarm, mainly depends on the amount of useful energy on board the drone-node. The greater the supply of energy and the lower its consumption, the longer the drone can function: move and provide communication. Determining a rational balancing between all types of expenses for the needs of drones functioning is vital. The key factors in the group work of drones in the swarm are miniaturization and cost. These are the two main problems when creating large groups of drones. Hence, the simplicity of each swarm node should be given special attention, and an approach using swarm intelligence to achieve meaningful behavior at the group level, and not at the individual level, is justified. Also, the key factor is the need to have a mechanism for "recovering" the swarm (or "survival") if it is damaged (disrupting the operation of a number of drones or links between them) or disintegrating. 


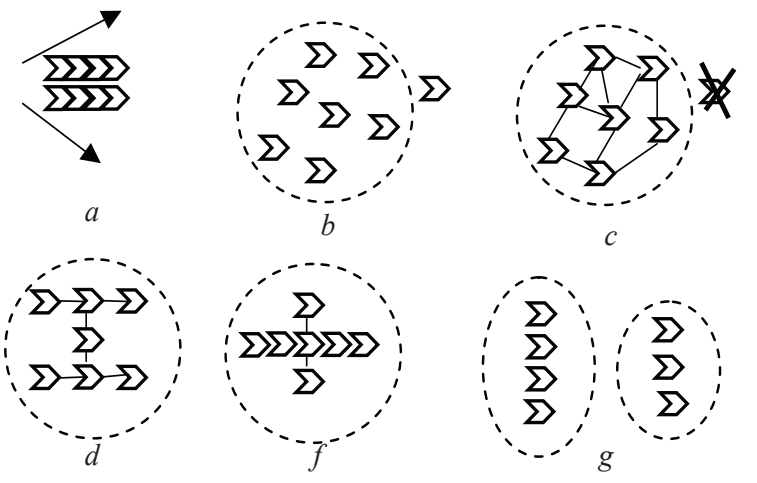

Fig. 5. Swarm Work Life Cycle

The following work stages (life cycle) of the swarm can be distinguished:

1) start: the release or launch of drones-nodes from which a given swarm will have to be formed (Fig. 5, a);

2) structuring: the initial determination and adjustment of the location of drones in a given (target) spatial domain. At the same time, swarm nodes (drones) (after their "ejection" or "launch") are located, practically, arbitrarily in a certain threedimensional spatial domain. That is, the area where drones will be able to self-organize with reference to a specific location or direction (Fig. 5, b);

3) formation: an attempt is made to interact between drones inside the swarm area, to identify and eliminate drones that cannot communicate with other (identified) drones. When all the swarm drones available for interaction and selforganization are identified, the "losses" of the drones are assessed and how these "losses" affected the given target of the swarm's actions. Depending on the results of such an assessment, two mutually exclusive options are possible: the continuation of the mission or its interruption with the possible elimination of the identified drones. Subsequent connection to the external control channel is realized provided that the previous specified swarm action program has been completed (Fig. 5, c);

4) self-organization: produced using internal (between drones) control and monitoring channels. In this case, the swarm immediately independently proceeds to the implementation of the task assigned to it, mainly without being connected to external control channels. The period of such spatial self-organization is limited according to the required security protocol (Fig. 5, d);

5) reconfiguration: after the assigned task is completed, the swarm proceeds to the next programmed task or outputs external control channels to receive new tasks from outside (Fig. 5, f);

6) disbanding or recycling: after the assigned task is completed, a swarm may be disbanded in order to use its drones-nodes to form new swarms. Disposal ensures the liquidation of the swarm-nodes of the swarm, which guarantees the impossibility of the repeated use of drones by other parties (Fig. 5, g).

The practical scenario of the spatial self-organization of the swarm-nodes of the swarm, which we called "molecular" (like the formation of a complex molecule from atoms by forming certain bonds with each other), can be followed by "chain" and "flash" procedures. The "chaining" procedure implies the establishment of links between nearby located nodes with the formation of pairs of nodes that form the chain structure. The "flash" procedure implies the simultaneous activation of drones and their instant fixation. Not caught under the "flash" drones are tightened "chain." The "flash" can be repeated as many times as necessary. If head drones are provided in the swarm, they can periodically monitor the signals, waiting for the detection of "lost" drones-nodes. In this case, the head drones can move, choosing the desired position for more effective monitoring.

\section{STRATEGY FOR COLLECTIVE CONTROL OF THE DRONE SWARM}

The methodology of flight of individual unmanned aerial vehicles (UAVs) has been elaborated in detail in detail [35]. However, the practice of solving different tasks, including defense ones, requires studying a fundamentally new control object - an aggregate (group, grouping, swarm) of aircrafts that carry out joint movement or along relatively close trajectories, or form a complex space-time structure of the mutual position of objects. This is especially true now for tracking and controlling a swarm of drones $[36,37]$.

In the tasks of observing such objects, one often also has to deal with a situation that consists not of one, but of a set of objects of accompaniment. Many of the objects of support can be divided in the process of their movement, forming new groups or independent separate objects. The relevance of understanding the methods of building such complex groups and the forecast of their movement in modern conditions not only remains, but even increases.

One of the important factors for achieving success in the implementation of armed struggle in modern conditions is the complex use of the available combat means and capabilities. This allows us to conclude that group actions should be considered the main modern form of using combat potential. The study of the movement of a group of UAVs and the requirement of tracking them, predicting the simultaneous flight of a group of different types of UAVs make it necessary to develop new algorithms and methods, as a rule, analytical, since even very powerful computing resources are unable to provide solutions to such multidimensional problems.

In particular, the general theory of group control of robots in dynamic, non-deterministic environments was developed in $[38,39]$. It provides a classification by the level of the algorithmic complexity of the tasks of group control of robots for various conditions of their application. It is shown that for the organization of control systems of groups of robots it is advisable to use some general strategies used to control all technical, social and natural groups. The strategies of centralized, decentralized and combined management are highlighted. In the most general case, it is recommended to include the group action planning subsystem, local on-board control systems of individual group robots responsible for 
implementing group actions, and on-board actuators of individual robots in the group control system for robots.

The proposed approach is based on the principles of collective management and the following provisions:

- each team member independently forms the management and determines his actions in the current situation (selforganization)

- the choice of actions by team members is carried out only on the basis of information about the goal of the team, the situation in the environment at the current time, current states and actions of other team members (cooperative interaction)

- as the optimal action of a member of a collective, is understood such an action that makes the greatest possible contribution to the achievement of a common goal (flexibility and rationality only of certain actions);

- accepting trade-offs is allowed (management is difficult, the possibility of using artificial intelligence).

The task is to select and perform at the current time a group of drones of such group actions that provide an extremum (maximum, if benefits from actions of a group of drones are estimated, or minimum, if expenses are estimated) of the target functional taking into account the vector of opposing forces on a discrete time interval. An approach to solving the discrete task of collective control of a group of drones, based on the use of an iterative procedure, in which drones consistently choose their next actions, is proposed.

Taking into account modern realities and the possibility of group movement, it is important to model information exchange processes between UAVs. Neither models based on the representation of motion in the form of differential equations, nor the neural and fuzzy models presented above have such properties and no such modeling functions. Because of this, to solve modern problems of flight theory, it is necessary to use concepts that allow one to be "above" traditional approaches to the definition of motion. As the study of various methods of presenting and describing the behavior of active objects in changing external environments (adaptive, what is organized, finite automata, etc.) shows, it is advisable to use the paradigm of agent-oriented systems and the concept of intelligent agent (IA) to simulate such situations high-level abstraction for the formalization of complex not to certain situations [40]. In this case, the actual movement of aircraft is expediently described as the movement in space of such intelligent agents.

Intelligent agents are a new class of some software and hardware entities that find and process information that support solving difficult problems, are able to conduct independent "negotiations" in software systems, automate routine operations and cooperate with other software agents when complex problems arise, thereby removing human excess information load (Fig. 6). An agent in the general case is a system that functions inside a certain environment, capable of sensing the environment with the help of sensors and influencing it (in our case, moving in it) to perform its own program of actions. The determining factor in multi-agent systems is the communication system. The ability to exchange information extends the competencies of agents, allowing them to use the knowledge of other agents. It also provides the conditions for effective task redeployment and coordination.

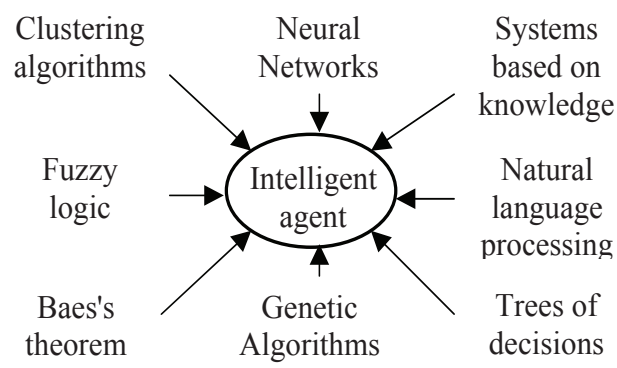

Fig. 6. Algorithms for intelligent decision-making agent

Based on the above, the following definition can be given: the agent is an independent software system:

- has the ability to perceive influence from the outside world;

- determines its response to this impact and forms the corresponding action;

- changes its behavior over time depending on the accumulated information and knowledge extracted from it;

- has motivation and is able, after delegation of authority by the user, to put himself in his place and make a decision appropriate to the situation.

An intelligent agent must have the following properties:

- autonomy - the ability to function without interference from its owner and to monitor the internal state and their actions;

- adaptability - the agent has the ability to learn and adapt to changes in external conditions;

- cognition - an agent can interact with other agents in several ways, playing different roles, using the resources of other agents by agreement;

- ability to make decisions - agents may have partial knowledge or decision-making mechanisms, as well as specialize in a specific subject area;

- communicatively - agents can communicate with other agents;

- mobility - the ability to transfer agent code from one server to another;

- social behavior - the possibility of interaction and communication with other agents;

- reactivity - adequate perception of the environment and the corresponding reactions to its changes;

- activity - the ability to generate goals and act rationally to achieve them;

- availability of basic knowledge - knowledge of the agent about itself, the environment, including other agents that do not change within the life cycle of the agent;

- availability of accumulated knowledge - a variable part of basic knowledge that may change over time;

- the presence of a goal - a set of states at which the current behavior of the agent is directed; 
- the presence of prerogatives - conditions and situations, the achievement of which for an agent is important, is compared with the existing goal;

- temporary tasks - tasks that an agent undertakes at the request and / or instructions of other agents are compared with the existing goal.

The following constructions of some management strategies can be proposed.

Centralized management with Master. The group is assigned the lead Master node. His behavior is determined from the Center, which is in constant communication with the Master. Other elements may follow the Master in accordance with the "flock" natural algorithms with the formation of the corresponding structure (chain, star, etc.), Realizing the "dolike-me" behavior, or form a hierarchical structure that implements clear subordination. A variant can be implemented in which the Master determines the target distribution and issues a task for the UAV group. Such a strategy, according to some estimates, turns out to be more resistant to counteraction by the opposite side of the conflict, with the implementation of reduced requirements for information support of the entire grouping, means of communication. In general, the role of the Master can be assigned to any UAV group, has the necessary competencies. The facilitator can be changed by a command from the Control Center, which can also increase the effectiveness of using the strategy in different conditions.

Decentralized management with the Master. This strategy also assigns the leader, who is assigned the task for the whole grouping, but in the future the Center is not connected with him, and the Master makes decisions on the distribution and target checks of the distribution of the entire group independently. Such a strategy places a great responsibility on the Master. In fact, this strategy is already becoming intellectual, but decision making in it is still based on the principle of unity of command - centralized management.

Collective self-management with the exchange of information. Such a strategy is connected with the fact that the objects of management act independently, but they exchange information with each other for decision-making and further movement in accordance with the decisions taken. This strategy differs from the previously considered clearly defined collectivism of behavior. The main problem here may be the need to solve conflict problems that will invariably arise with such a management strategy.

Decentralized management with prediction. In the framework of decentralized management with the Master or collective self-government with the exchange of information grouping may assign/allocate IA, which will solve the problems in the pre-threatening movement throughout the zone of groups, that is a kind of "spy-predictor." A spy, moving along pre-agreed or chosen trajectories depending on the situation, can inform other IAs of the degree of danger of the path being traveled. To select the best routes, for example, "ant" algorithms can be used here.

Self-organization without sharing information. This variant of control in the conditions of movement in an antagonistic environment with active counteraction may become the only possible one. But disunity has never contributed to the overall performance of common tasks, and the lack of information sharing can significantly reduce efficiency. In addition, this option also requires early targeted distribution checks, reduces the flexibility of grouping.

The heterogeneity of an IA can introduce certain features in the construction of strategies, primarily due to the different flight-technical characteristics and capabilities of the various IAs included in the grouping. So, having a single Master can make it difficult to interact in a group; it is advisable to divide it into subgroups of similar IAs, with appropriate allocation of their own Masters and delegating relevant tasks for such a single subgroup. It is also possible to predict a significant difference in the spatial-temporal characteristics of different types of objects acting as part of a group. Indeed, provided that the group includes, for example, UAVs of four different types (airplanes, drones, aerostats), they can occupy essentially different height horizons and move in different azimuthal directions.

\section{CONClusion}

The basic principles and strategies for the formation of a heterogeneous wireless communication system based on a swarm of unmanned aerial vehicles have been developed. The following results were obtained.

The hardware and software base for building a swarm is the use of modern technologies of distributed cloud computing, self-organization, intellectualization, cooperative retransmission, cognitive radio, space-time processing, adaptation, SDR, SoC and SDN.

The main difference between a UAV swarm and a single UAV is the presence of a spatially distributed, rather than a concentrated structure, which is significantly more complex, but, because of its distributed nature, has a higher survivability and flexibility in providing communication services.

Scenarios of centralized and distributed building of a wireless network of control of a swarm of UAVs are presented, assessment of the complexity of the functionality of swarm nodes in the case of a distributed scenario is carried out.

A scheme of phased implementation of the life cycle of a UAV swarm for communication services has been developed. The "molecular" scenario of spatial self-organization of the swarm-nodes of the swarm is presented, which can be implemented using the "chain" and "flash" procedures.

A strategy has been developed for collectively managing a swarm of drones, which boils down to selecting and performing at the current time a group of drones of certain group actions that provide an extremum (maximum, if benefits from actions of a group of drones are estimated, or at least, if costs are estimated) on the interval of discrete time.

The proposed construction of some strategies for managing the swarm: centralized and decentralized with the Master, collective self-management with information sharing, decentralized management with forecasting, self-organization without information sharing. 


\section{ACKNOWLEDGMENT}

This work is carried out within the framework of state research projects (No 2120, state registration number (SRN) 0118 U003521 "Scientific and technical basis for building new over-horizon communications relay systems using artificial structures and aeroplatform") on request of the Ministry of Education and Science of Ukraine.

\section{REFERENCES}

[1] S. Braley, C. Rubens, T. Merritt and R. Vertegaal, "GridDrones: A SelfLevitating Physical Voxel Lattice for Interactive 3D Surface Deformations", CHI Conference on Human Factors in Computing Systems, Montreal QC, Canada, April 21-26, 2018 (doi>10.1145/3170427.3186477).

2] A. Levandovskiy, "Drones show: how we coordinated a swarm of dancing kopter", habr, 2018, (https://habr.com/ru/company/ croc/blog/427353/).

[3] In the US, test autonomous combat drones that will use the swarm tactics, Newsader, 2018, https://hvylya.net/news/digest/v-sshatestiruyut-avtonomnyih-boevyih-dronov-kotoryie-budut-ispolzovattaktiku-roya.html

[4] Security of Self-Organizing Networks: MANET, WSN, WMN, VANET, edited by A.-S. K. Pathan: CRC Press, 594 p., 2011.

5] Self-Organized Mobile Communication Technologies and Techniques for Network Optimization, edited by A. Diab: Information Science Reference, 416 p., 2016.

[6] M.Y. Ilchenko, S.O. Kravchuk, Telecommunication systems: Kyiv, Naukova dumka, 2017, 736 p. (ISBN: 978-966-00-1566-1), (in Ukraine).

[7] M.Yu. Ilchenko, S.O. Kravchuk, "Convergence of the Fixed and Mobile Informational-Telecommunicational Platforms and Networks", Research Bulletin of NTUU "KPI", Issue 5, pp. 7-13, 2013.

[8] S.O. Kravchuk, D.A. Minochkin, "Application of distributed computing in telecommunication systems", Scientific papers coll. of the Military Institute of Kyiv National University. Shevchenko, Issue 50, pp. 41-44, 2015.

[9] Mobile Ad Hoc Networks: Current Status and Future Trends, by edition J. Loo, J. L. Mauri, J. H. Ortiz, CRC Press, 2012, 538 p. (ISBN 9781439856505)

[10] I. Chlamtac, M. Conti, J. J.-N. Liu, "Mobile ad hoc networking: imperatives and challenges", Ad Hoc Networks, 1, pp. 13-64, 2003 (doi:10.1016/S1570-8705(03)00013-1).

[11] J. Wang, Y. Shao, Y. Ge, R. Yu, "A Survey of Vehicle to Everything (V2X) Testing”, Sensors, Vol. 19, Issue 2, 2019 (DOI:10.3390/s19020334).

[12] Swarm Robotics, edited by S. Giandomenico: Mdpi AG, 2019, 312 p. (ISBN 10 3038979228, 13 978-3038979227)

[13] K. N. Doan, A. T. Le, T. D. Le, N. Peter, Swarm Robots' Communication and Cooperation in Motion Planning: Springer, 2017

[14] P. Benavidez, K. Nagothu, A.K. Ray, T. Shaneyfelt, S. Kota, L. Behera, M. Jamshidi, "Multi-domain robotic swarm communication system", IEEE International Conference on System of Systems Engineering, 2-4 June 2008 (DOI: 10.1109/SYSOSE.2008.4724189).

[15] G. Nagar, A. Sood, M. Roopak, "Swarm Intelligence for Network Communication Routing", Journal of Computer Science and Information Technology, Vol. 2, Issue. 5, pp. 268 - 274, 2013

[16] M. Zgurovsky, M. Ilchenko, S. Kravchuk, V. Kotovskyi, T. Narytnik, L. Cybulskyi, "Prospects of using of aerial stratospheric telecommunication systems", Proceedings of the 2016 IEEE International Scientific Conference "RadioElectronics \& InfoCommunications" (UkrMiCo'2016), 11-16 September 2016, Kyiv, Ukraine. IEEE Conference Publications, pp. 20-23, 2016 (IEEE Xplore Digital Library, DOI: 10.1109/UkrMiCo.2016.7739636)

[17] M. Ilchenko, S. Kravchuk, Telecommunication systems based on highaltitude aerial platforms: Naukova Dumka, 580 p., 2008 (ISBN 978-96600-0715-4) (ru).
[18] S.O. Kravchuk, L.O. Aphanasieva, "Resources distribution for the telecommunication systems based on aero-platform", Dig. of the 12th International Scientific conf. "Modern Challenges in Telecommunications", april 16-20, 2018, Kyiv, Ukraine, pp. 201-204, 2018 (https://scholar.google.com.ua/scholar?oi=bibs\&cluster= $13889311223405809219 \&$ btnI $=1 \&$ hl $=$ uk)

[19] M.Y. Ilchenko, M.M. Kaydenko, S.O. Kravchuk, "Structural-functional principles of management and communication systems for border and landscape equipment of the telecommunication network on the basic of aeroplatform", Dig. of the 12th International Scientific conf. "Modern Challenges in Telecommunications", april 16-20, 2018, Kyiv, Ukraine, pp. 26-29, 2018 (https://scholar.google.com.ua/scholar?oi= bibs\&cluster $=7645924388419038907 \& b \operatorname{tnI}=1 \& \mathrm{hl}=\mathrm{uk}$ ).

[20] L. Afanasieva, D. Minochkin, S. Kravchuk, "Providing telecommunication services to antarctic stations", Proceedings of the 2017 International Conference on Information and Telecommunication Technologies and Radio Electronics (UkrMiCo) 11-15 Sept. 2017 Year, Odessa, Ukraine, IEEE Conference Publications, pp.1-4, 2017 (IEEE Xplore Digital Library, DOI: 10.1109/UkrMiCo.2017.8095419).

[21] S. Kacapyr, "Cracker-sized satellites demonstrate new space tech", Cornell Chronicle, 2019 (http://news.cornell.edu/stories/2019/06/ cracker-sized-satellites-demonstrate-new-space-tech).

[22] S.O. Kravchuk, I.M. Kravchuk, "Implementation of the MIMO-system for HAPS by forming a virtual antenna array", Dig. of the 12th International Scientific conf. "Modern Challenges in Telecommunications", april 16-20, Kyiv, Ukraine, pp. 177-180, 2018, (https://scholar.google.com.ua/scholar?oi=bibs\&cluster= $17611274762564973506 \& b \operatorname{tnI}=1 \& \mathrm{hl}=\mathrm{uk}$ ).

[23] M. Mozaffari, W. Saad, M. Bennis, M. Debbah, "Communications and Control for Wireless Drone-Based Antenna Array", IEEE Transactions on Communications, Vol. 67, Issue 1, pp. 820-834, 2019.

[24] S.O. Kravchuk, "Unmanned aerial vehicle as a mobile M2M-gateway for smart ubiquitous network", Dig. of the 13th International Scientific conf. "Modern Challenges in Telecommunications", 2019, Kyiv, Ukraine, 2019 (https://scholar.google.com.ua/scholar?oi=bibs\&cluster= $2119678573849458940 \&$ btnI $=1 \&$ hl=uk).

[25] O. Shrit, S. Martin, K. Al Agha, G. Pujolle, "A new approach to realize drone swarm using ad-hoc network", 2017 16th Annual Mediterranean Ad Hoc Networking Workshop (Med-Hoc-Net), Jun 2017, Budva, Montenegro. IEEE, 2017, <10.1109/MedHocNet.2017.8001645>. <hal$01696735>$

[26] M. Kuzmich, S. Kravchuk, "Research mobile drones mesh-network taking into account delay between nodes", Dig. of the Eleventh International Scientific conf. "Modern Challenges in Telecommunications", april 18-21, 2017, Kyiv, Ukraine, pp. 196-198, 2017 (https://scholar.google.com.ua/scholar?oi=bibs\&cluster= $11046824751924574754 \& \mathrm{btnI}=1 \& \mathrm{hl}=\mathrm{uk})$

[27] S.O. Kravchuk, "Radio-channel access control scheme for meshnetwork based aeroplatform", Dig. of the Tenth International Scientific conf. "Modern Challenges in Telecommunications", april 19-22, 2016, Kyiv, Ukraine, pp. 302-304, 2016 (https://scholar.google.com.ua/ scholar?oi=bibs\&cluster=8459254762897009932\&btnI=1\&hl=uk).

[28] A. Fotouhi, H. Qiang, M. Ding, M. Hassan, L. G. Giordano, A. GarciaRodriguez, J. Yuan, "Survey on UAV Cellular Communications: Practical Aspects, Standardization Advancements, Regulation, and Security Challenges", Journal of Communications Surveys and Tuturials Mar 2019

[29] T. Zeng, M. Mozaffari, O. Semiari, W. Saad, M. Bennis, and M. Debbah, "Wireless Communications and Control for Swarms of Cellular-Connected UAVs", IEEE Conferences 52nd Asilomar Conference on Signals, Systems, and Computers, pp. 719-723, 2018 (doi:10.1109/acssc.2018.8645472)

[30] M. Mozaffari, W. Saad, M. Bennis \& M. Debbah, "Drone Small Cells in the Clouds: Design, Deployment and Performance Analysis", 2015 IEEE Global Communications Conference (GLOBECOM), 2014 (doi:10.1109/glocom.2014.7417609).

[31] S.O. Kravchuk, "Outage probability of communication in a cognitive radio system based on an aeroplatformy", Dig. of the 12th International Scientific conf. "Modern Challenges in Telecommunications", april 1620, 2018, Kyiv, Ukraine, pp. 161-164, 2018 
(https://scholar.google.com.ua/scholar?oi=bibs\&cluster=882291927766 $0762590 \& \mathrm{btnI}=1 \& \mathrm{hl}=\mathrm{uk})$.

[32] S.O. Kravchuk, I.M. Kravchuk, "Outage probability of communication in the telecommunication system based aeroplatfom with the employment of cross-platform optical channel in free space", Dig. of the 12th International Scientific conf. "Modern Challenges in Telecommunications", april 16-20, 2018, Kyiv, Ukraine, pp. 194-197, 2018 (https://scholar.google.com.ua/scholar?oi=bibs\&cluster= $15119675460130244373 \&$ btnI $=1 \& \mathrm{hl}=\mathrm{uk}$ )

[33] M. Ilchenko, S. Kravchuk, M. Kaydenko, "Combined Over-the-Horizon Communication Systems", In: Advances in Information and Communication Technologies. Processing and Control in Information and Communication Systems. UKRMICO 2018. Lecture Notes in Electrical Engineering, vol 560. Springer, Cham, 2019 - P. 121-145. DOI: 10.1007/978-3-030-16770-7 (https://doi.org/10.1007/978-3-03016770-7_6).

[34] M. Ilchenko, S. Kravchuk, D. Minochkin, L. Afanasieva, Troposcatter communication link model based on ray-tracing, Information and Telecommunication Sciences, No 2, pp. 15-20, 2018 (DOI: https://doi.org/10.20535/2411-2976.22018.15-20).

[35] A.A. Dmitrievsky, L.N. Lysenko, External ballistics. M $\therefore$ Mashinostroenie, 2005. - $608 \mathrm{p}$.
[36] S.O. Kravchuk, I.M. Kravchuk, "Approaches and strategies for collective management swarm of drones", Dig. of the 13th International Scientific conf. "Modern Challenges in Telecommunications", april 1519, 2019, Kyiv, Ukraine, 2019, p. 170-174 (https://scholar.google.com.ua/scholar?oi=bibs\&cluster=172694151156 $37797517 \& \mathrm{btnI}=1 \& \mathrm{hl}=\mathrm{uk}$ )

[37] S.O. Kravchuk, L.O. Aphanasieva, I.M. Kravchuk, "Hierarchical control system and telemetry for intelligent unmanned aerial vehicles", Dig. of the 12th International Scientific conf. "Modern Challenges in Telecommunications", april 16-20, 2018, Kyiv, Ukraine, pp. 187-190, 2018 (https://scholar.google.com.ua/scholar?oi=bibs\&cluster= $11535379666139610503 \&$ btnI=1\&hl=uk).

[38] S.G. Kapustyan, Methods and algorithms for collective control of robots in their group use. Rostov-on-Don, 2008. - 310 p.

[39] V. Abrosimov, Group movement of intelligent aircraft in antagonistic environment: monograph. - M .: Izdat. House "Science", 2013. - 168 p.

[40] K.S. Amelin, O.N. Grachinin, "Multi-agent network management of a group of light UAVs", Neurocomputers: development, application, № 6, pp. 64-72, 2011

\section{Кравчук С.О., Афанасьева Л.О. \\ Формування безпроводової системи зв'язку на основі рою безпілотних літаючих апаратів}

Проблематика. На даний час бурхливо розвивається новий напрямок в техніці рухомих систем, пов'язаний із застосуванням множини/групи рухомих багатофункціональних вузлів, які можуть створювати різні простороворозподілені структури для різних застосувань: від розважальних шоу, до розвідувальної мережі. Йдеться про техніку малих безпілотних літальних апаратів (БЛА), частіше званих дронами, та їх використання в області побудови телекомунікаційних систем.

Мета. Метою роботи є розробка основних принципів і стратегій для формування неоднорідної безпроводової системи зв'язку на базі рою безпілотних літаючих апаратів.

Методи. Досліджуються структурно-функціональні методи побудови безпроводової мережі.

Результати. Представлені сценарії централізованої і розподіленої побудови безпроводової мережі керування рою БЛА, проведена оцінка ускладнення функціональності вузлів рою в разі розподіленого сценарію. Розроблено схему поетапної реалізації життєвого циклу рою БЛА для послуг зв'язку. Представлений «молекулярний» сценарій просторової самоорганізації дронів-вузлів рою, який може бути реалізований за допомогою процедур «ланцюжка» і «спалаху». Запропоновано побудови деяких стратегій управління роєм: централізоване і децентралізоване з Ведучим, колективне само керування з обміном інформацією, децентралізоване керування 3 прогнозуванням, самоорганізація без обміну інформацією.

Висновки. Розроблено основні принципи і стратегії формування неоднорідної безпроводової системи зв'язку на базі рою безпілотних літаючих апаратів. Розроблено стратегію колективного управління роєм дронів.

Ключові слова: рій безпілотних літаючих апаратів; рій дронів; система зв'язку; життєвий цикл; мережа керування.

Кравчук С.А., Афанасьева Л.А.

Формирование беспроводной системы связи на основе роя беспилотных летающих аппаратов

Проблематика. В настоящее время очень бурно развивается новое направление в технике подвижных систем, связанное с применением множества/группы подвижных многофункциональных элементов, которые могут создавать различные пространственно-распределенные структуры для различных применений: от развлекательных шоу, до разведывательной сети. Речь идет о технике малых беспилотных летающих аппаратов (БЛА), чаще называемых дронами, и их использование в области построения телекоммуникационных систем.

Цель. Целью работы является разработка основных принципов и стратегий для формирования неоднородной беспроводной системы связи на базе роя беспилотных летающих аппаратов.

Методы. Исследуются структурно-функциональные методы построения беспроводной сети.

Результаты. Представлены сценарии централизованного и распределенного построения беспроводной сети управления роя БЛА, проведена оценка усложнения функциональности узлов роя в случае распределенного сценария.

Разработана схема поэтапной реализации жизненного цикла роя БЛА для услуг связи. Представлен «молекулярный» сценарий пространственной самоорганизации дронов-узлов роя, который может быть реализован посредством процедур 